\begin{tabular}{r|l|l|l}
$\begin{array}{c}\text { Case Reports in } \\
\text { Gastroenterology }\end{array}$ & $\begin{array}{l}\text { Case Rep Gastroenterol 2010;4:457-464 } \\
\text { DOl: 10.1159/000321989 }\end{array}$ & $\begin{array}{l}\text { Published online: } \\
\text { October 22, 2010 }\end{array}$ & $\begin{array}{l}\text { O 2010 S. Karger AG, Basel } \\
\text { ISSN 1662-0631 } \\
\text { www.karger.com/crg }\end{array}$ \\
\hline
\end{tabular}

\title{
Lipomatous Pseudohypertrophy of the Pancreas Taking the Form of Huge Massive Lesion of the Pancreatic Head
}

\author{
Masanari Shimada ${ }^{a}$ Kazushige Shibahara ${ }^{a}$ \\ Hirotaka Kitamura ${ }^{a}$ Yoshitaka Demura ${ }^{a}$ Masahiro Hada ${ }^{a}$ \\ Akira Takehara $^{a}$ Zensei Nozaki ${ }^{a}$ Masatoshi Sasaki ${ }^{a}$

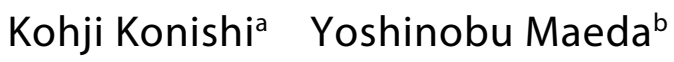

Departments of aSurgery and ${ }^{b}$ Pathology, Toyama Red Cross Hospital, Toyama, Japan

\section{Key Words}

Lipomatous pseudohypertrophy · Pancreas · Pancreatic head · Pancreatic neoplasm

\begin{abstract}
A 70-year-old woman presented with hypogastric pain. Computed tomography and magnetic resonance imaging revealed a retroperitoneal tumor $18.0 \mathrm{~cm}$ in diameter with fatty tissue density, ventrally compressing the pancreatic head. We suspected a well-differentiated liposarcoma compressing the pancreas. At laparotomy, the tumor mass was the size of an infant's head; its center was located in the area corresponding to the pancreatic uncus. It was continuous with the pancreatic parenchyma through a poorly demarcated border, and we resected as much of the tumor mass as possible while conserving the pancreatic capsule. Histopathological examination indicated lipomatous pseudohypertrophy of the pancreas with proliferation of mature fatty tissue as the main constituent. At the periphery, islands of acinar tissue were retained among the fatty infiltration, which also contained branches of the pancreatic duct and islets of Langerhans. Previous reports have stated that this disorder only causes fatty replacements throughout the pancreas or in the pancreatic body and tail; however, in this patient, imaging and macroscopic examination revealed no fatty replacements in the pancreatic body and tail. We report this case, which we consider extremely rare, along with a brief review of the literature.
\end{abstract}




\begin{tabular}{r|l|l|l}
$\begin{array}{r}\text { Case Reports in } \\
\text { Gastruanteriology }\end{array}$ & $\begin{array}{l}\text { Case Rep Gastroenterol 2010;4:457-464 } \\
\text { DOI: 10.1159/000321989 }\end{array}$ & $\begin{array}{l}\text { Published online: } \\
\text { October 22, 2010 }\end{array}$ & $\begin{array}{l}\text { O 2010 S. Karger AG, Basel } \\
\text { ISSN 1662-0631 } \\
\text { www.karger.com/crg }\end{array}$ \\
\hline
\end{tabular}

\section{Introduction}

Lipomatous pseudohypertrophy ( $\mathrm{LiPH})$ of the pancreas is an extremely rare disease of unknown cause in which pancreatic tissue is replaced by proliferating fatty tissue. In most patients either the whole pancreas or only the pancreatic tail enlarges; however, here we report an extremely rare case in which $\mathrm{LiPH}$ was limited to the pancreatic head.

\section{Case Report}

The patient was a 70-year-old woman. She had a medical history of angina pectoris and hyperlipidemia, and had undergone surgery for an ovarian cystic tumor. She presented to the department of internal medicine of our hospital with a one-month history of hypogastric pain. Computed tomography (CT) indicated a tumor mass in the dorsal pancreas, and she was therefore referred to our department for further investigation and treatment. She was $153.0 \mathrm{~cm}$ tall and weighed $58.0 \mathrm{~kg}$ (body mass index $24.8 \mathrm{~kg} / \mathrm{m}^{2}$ ), and had no clinical signs of anemia or jaundice. The abdomen was flat and soft, with no tenderness. The tumor mass was not palpable. Laboratory investigations revealed no particular biochemical or hematological abnormalities. Tumor markers and hepatitis serology were also negative.

In CT a tumor mass with a maximum diameter of approximately $18.0 \mathrm{~cm}$ was visible, extending from the porta hepatis to the hypogastric region. It had the density of fatty tissue, and its interior was the same density as soft tissue. The pancreatic head was ventrally compressed and extended, but the tumor did not appear to directly invade the pancreas. Mediolaterally, the tumor surrounded the superior mesenteric artery and vein (fig. 1). In magnetic resonance imaging (MRI) pancreatic head mass lesions were present in the shape of ellipsoids extending from the porta hepatis to anterior to the vena cava inferior and reaching the pelvic cavity. On T1- and T2-weighted images, the tumor contained areas with similar signal intensity to subcutaneous and intraabdominal fat. Fat suppression MRI eliminated the signals from these areas, suggesting that the mass contained adipose tissue (fig. 2 ).

Laparotomy revealed a tumor mass with a thin capsule that was primarily located dorsal to the duodenum. The mass extended from the hepatoduodenal ligament cranially to dorsal to the transverse mesocolon caudally. By means of the Kocher maneuver, the tumor mass, pancreatic head, and duodenum were mobilized up to the ligament of Treitz, and the anatomical relationship was determined. From the pancreatic uncus the head region was strongly compressed and thinned, and the border with the tumor mass was unclear. The pancreatic parenchyma was scattered on the surface of the tumor mass. Complete enucleation of the tumor was impossible because the limits of the tumor mass capsule could not be clearly identified. We preserved as much of the capsule of the pancreatic head as possible to avoid damaging the principal pancreatic duct, and performed resection by partitioning the tumor mass. Since we were concerned about creating a pancreatic fistula we sited a pleated drain on the inferior surface of the liver and a suction drain on the dorsal pancreas before completing surgery (fig. 3).

Histopathologically the surgical specimen was an elastic and soft, xanthochromatic, lobulated tumor mass resembling adipose tissue. Its maximum dimensions were $18.0 \times 11.0 \times 6.0 \mathrm{~cm}$, and it weighed approximately $600 \mathrm{~g}$. The proliferation of mature fatty tissue was observed throughout the tumor mass. Islands of acinar tissue were present mainly in the periphery of the tumor mass. The fatty tissue contained fine, rudimentary branches of intervening pancreatic duct. Chromogranin A staining revealed that islets of Langerhans had remained intact, and cytokeratin 19 staining confirmed the presence of pancreatic duct epithelial cells. Whereas the pancreatic duct and islets of Langerhans components had remained relatively intact, acinar tissue was damaged and mostly replaced with fat infiltration. The presence of dysplastic cells was not seen, and well-differentiated liposarcoma was ruled out. Therefore the patient was diagnosed with LiPH of the pancreas (ig. $\underline{4})$.

On postoperative day 7 (POD7), surgical drainage indicated a pancreatic fistula. Since the amylase level in the drainage fluid became elevated at 200,000 IU/l, a continuous infusion of octreotide was started, and on POD21 the drain was exchanged for an aspiration drain. Serum trypsin and lipase levels at that time were high, and we were convinced that the exocrine function of the remaining pancreas was preserved. Since the pancreatic fistula also persisted, endoscopic retrograde cholangio-pancreatography 


\begin{tabular}{r|l|l|l} 
Case Reports in & $\begin{array}{l}\text { Case Rep Gastroenterol 2010;4:457-464 } \\
\text { DOl: 10.1159/000321989 }\end{array}$ & $\begin{array}{l}\text { Published online: } \\
\text { October 22, 2010 }\end{array}$ & $\begin{array}{l}\odot \text { ISSN 1662-0631 } \\
\text { www.karger.com/crg }\end{array}$ \\
\hline
\end{tabular}

was performed on POD28 to evaluate the principal pancreatic duct, and fortunately major leakage from this duct was not identified. From POD35 amylase levels in the drainage fluid started to fall, and the amount of fluid drained also decreased. On POD63 drainage was discontinued, and the fistula was thought to be almost closed since POD77. The patient was discharged from hospital on POD82. Six months later, CT showed no new fat tissue replacing the remaining pancreatic head to body or pancreatic tail.

\section{Discussion}

$\mathrm{LiPH}$ of the pancreas is an extremely rare disease that is defined by (1) the enlargement and increased weight of the pancreas and morphological uniformity of the pancreas, (2) complete replacement of the pancreatic exocrine tissue by fatty tissue, and (3) sparing of the pancreatic duct system and islets of Langerhans [1]. A literature search of Japana Centra Revuo Medicina and PubMed revealed only 27 other cases worldwide, including those in which the condition was diagnosed with imaging alone [1-16]. Unlike steatosis resulting from obstruction of the pancreatic duct by pancreatolithiasis or a tumor, the causal factors of this disease are unknown. Postulated causative mechanisms include congenital anomaly, pancreatic exocrine gland obstruction, and viral infection $[2,13]$.

The reported cases, including the present case, showed a wide range of age distribution from 9 months to 80 years, and comprised 16 males and 12 females. Affected sites included the entire pancreas ( 20 cases), body and pancreatic tail (3 cases), pancreatic head ( 4 cases), and uncinate ( 1 case). Besides the present case, there were only 4 cases in which $\mathrm{LiPH}$ developed in the pancreatic head $[15,16]$, hence this distribution appears to be extremely rare. The weight of the pancreas varied from $130 \mathrm{~g}$ to more than $1,200 \mathrm{~g}$; it was at least twice that of the normal pancreas, and in most cases 3 times or more $[6,13]$. Methods of diagnosis were autopsy (11 cases), surgery after diagnosis of liposarcoma or carcinoma (12 cases), and diagnostic imaging alone (5 cases). Symptoms did not determine diagnosis, and although many cases were accompanied by abnormal glucose tolerance or fatty liver, these abnormalities were not necessarily present [13]. Coexisting diseases included cirrhosis of the liver (including that due to hepatitis B) and primary sclerosing cholangitis $[9,10,15]$, and it seems possible that chronic liver injury influences the development of LiPH of the pancreas. Furthermore, cases have been reported in which LiPH developed as a complication of squamous cell carcinoma of the pancreas [8], so it is also necessary to examine association with malignant tumors. However, in the present case there were no obvious associated conditions.

Concerning differential diagnosis, although symptoms such as abdominal pain and anorexia raise the suspicion of liposarcoma, preoperative diagnosis is difficult [13]. In the present case, if magnetic resonance cholangio-pancreatography or endoscopic retrograde cholangio-pancreatography had been performed prior to surgery, we might have identified the pancreatic duct inside the tumor mass as normal. Further, if we had performed contrast CT we might have identified the vessel arcade of the pancreatic head at the periphery of the tumor mass.

Regarding intraoperative diagnosis, unfortunately it is generally difficult to diagnose fatty tissue by intraoperative frozen section. Indeed, the literature contains only one report that a sarcoma could be ruled out in this way [15]. Moreover, we did not suspect LiPH from intraoperative findings because the tumor is so rare. Therefore, if we had recognized LiPH, and if we could have differentiated between malign and 


\begin{tabular}{r|l|l|l} 
Case Reports in & $\begin{array}{l}\text { Case Rep Gastroenterol 2010;4:457-464 } \\
\text { DOI: 10.1159/000321989 }\end{array}$ & $\begin{array}{l}\text { Published online: } \\
\text { October 22, 2010 }\end{array}$ & $\begin{array}{l}\text { (ISSN 1662-0631 } \\
\text { www.karger.com/crg }\end{array}$ \\
\hline
\end{tabular}

benign manifestations from intraoperative macroscopic findings, we could have avoided excessive intrusion and might have prevented postoperative pancreatic fistula. At operation, fortunately the pancreatic head was almost normal and pancreaticoduodenectomy could be avoided; however, if we had expanded the scope of resection the main pancreatic duct would have been damaged, and complications might have been exacerbated. There are also reports in which standard pancreatic tail resection produced favorable results when the tumor mass was confined to the pancreatic tail $[5,13]$. Nonetheless, diagnosis requires prudence and resection methods must be selected carefully.

Since LiPH is a benign disorder, conservative management with regular follow-up is thought to be sufficient [13]. No specific therapies have been established for LiPH, but when symptoms of pancreatic exocrine function insufficiency are present, digestive enzymes including pancreatic enzymes are administered [14].

The rarity of LiPH of the pancreas means that the growth rate and time span of the progression of fat replacement are unknown, but the condition is considered to take several years to develop. Moreover, the initial site of LiPH is not clear. LiPH may begin from a certain point and gradually spread throughout other regions of the pancreas, it may gradually develop throughout the organ, or it may remain confined to a certain area. Thus in the present case it is possible that we observed a transitional phase and that the whole pancreas would have eventually been replaced by fat.

Taking the above information into account, we propose to roughly classify LiPH of the pancreas by the affected site into diffuse type, head-nodular type and tail-nodular type. While tail-nodular type LiPH can be safely resected by removing the pancreatic tail, safe resection is difficult in diffuse-type and head-nodular type $\mathrm{LiPH}$, and there are cases in which it might be necessary to restrict surgery to biopsy or subtotal resection. It should be possible to predict diffuse-type LiPH from diagnostic imaging. We believe that this classification is very important when considering treatment options for this condition. In the future, we hope that LiPH of the pancreas will be elucidated through long-term follow-up and the accumulation of further cases. 


\begin{tabular}{r|l|l|l}
$\begin{array}{r}\text { Case Reports in } \\
\text { Gastruenterology }\end{array}$ & $\begin{array}{l}\text { Case Rep Gastroenterol 2010;4:457-464 } \\
\text { DOI: 10.1159/000321989 }\end{array}$ & $\begin{array}{l}\text { Published online: } \\
\text { October 22, 2010 }\end{array}$ & $\begin{array}{l}\text { O 2010 S. Karger AG, Basel } \\
\text { ISSN 1662-0631 } \\
\text { www.karger.com/crg }\end{array}$ \\
\hline
\end{tabular}

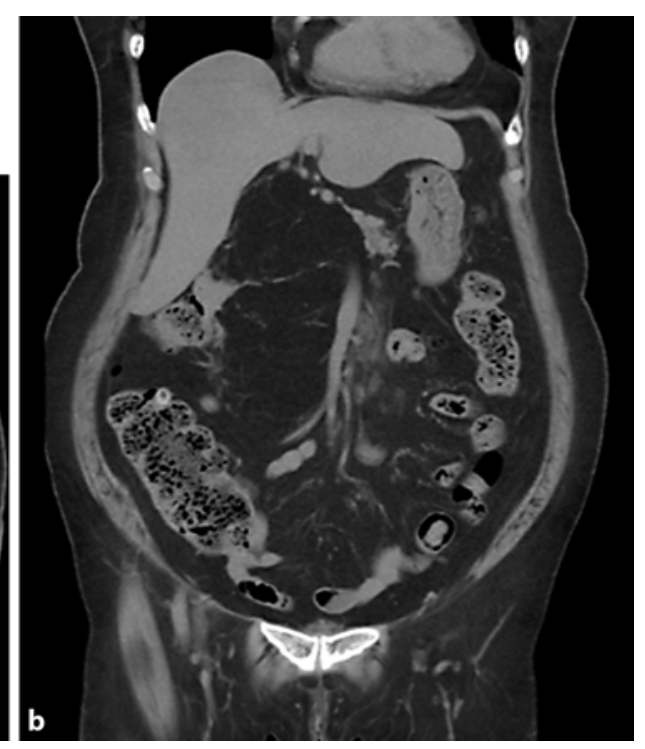

Fig. 1. Abdominal CT. A mass with the same intensity as fat was recognized in the lower abdomen, protruding below the liver. The mass had a maximum diameter of about $18.0 \mathrm{~cm}$. a Axial view. b Coronal view.
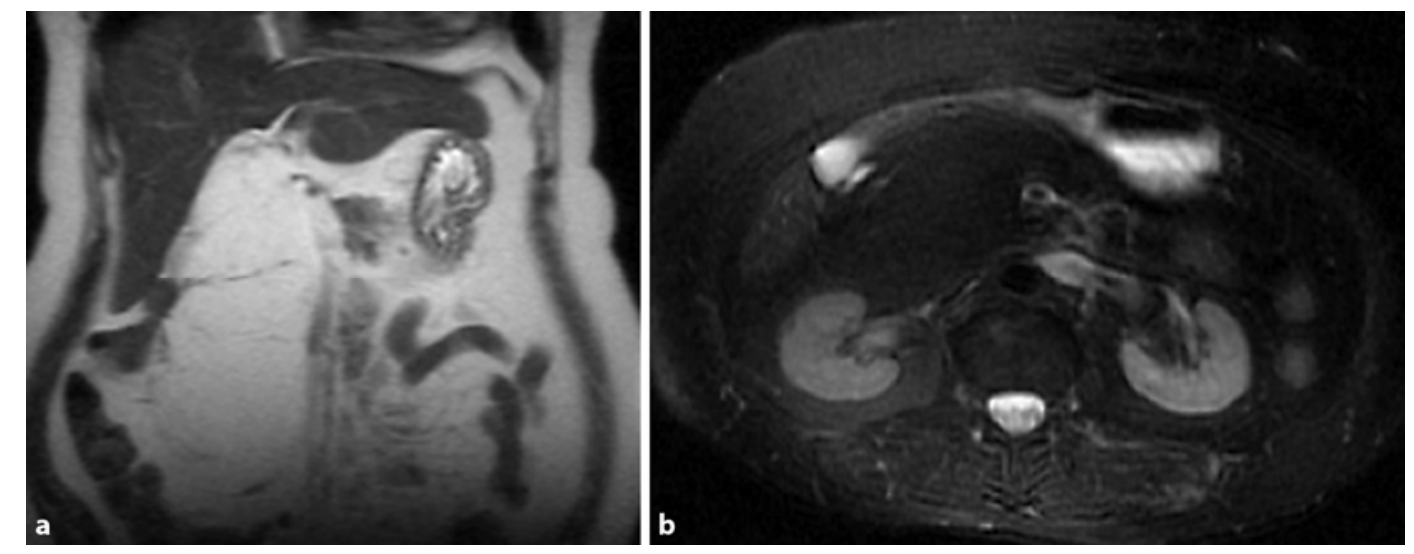

Fig. 2. MRI. The mass had high intensity on T1 imaging, and on T2 imaging it had a similar intensity to subcutaneous and intraperitoneal fat. Fat suppression eliminated the signals from the mass. a T2. b Fat suppression. 


\begin{tabular}{r|l|l|l}
$\begin{array}{r}\text { Case Reports in } \\
\text { Gastruanteriology }\end{array}$ & $\begin{array}{l}\text { Case Rep Gastroenterol 2010;4:457-464 } \\
\text { DOI: 10.1159/000321989 }\end{array}$ & $\begin{array}{l}\text { Published online: } \\
\text { October 22, 2010 }\end{array}$ & $\begin{array}{l}\text { O 2010 S. Karger AG, Basel } \\
\text { ISSN 1662-0631 } \\
\text { www.karger.com/crg }\end{array}$ \\
\hline
\end{tabular}

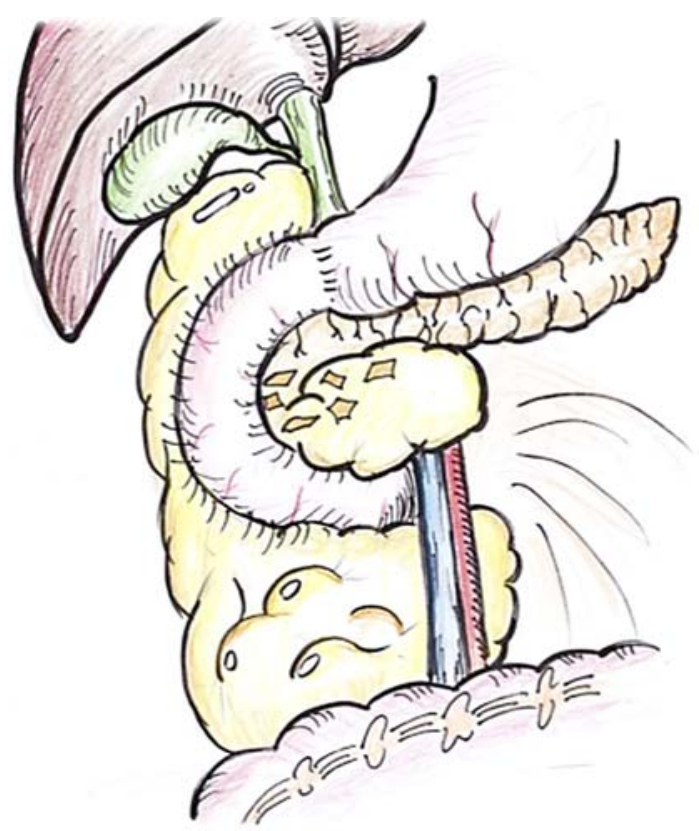

Fig. 3. Operative findings. The pancreatic uncus and head had been partially replaced by the mass and were thin, and the mass did not have clear borders. 


\begin{tabular}{r|l|l|l} 
Case Reports in & $\begin{array}{l}\text { Case Rep Gastroenterol 2010;4:457-464 } \\
\text { DOl: 10.1159/000321989 }\end{array}$ & $\begin{array}{l}\text { Published online: } \\
\text { October 22, 2010 }\end{array}$ & $\begin{array}{l}\odot \text { ISSN 1662-0631 } \\
\text { www.karger.com/crg }\end{array}$ \\
\hline
\end{tabular}
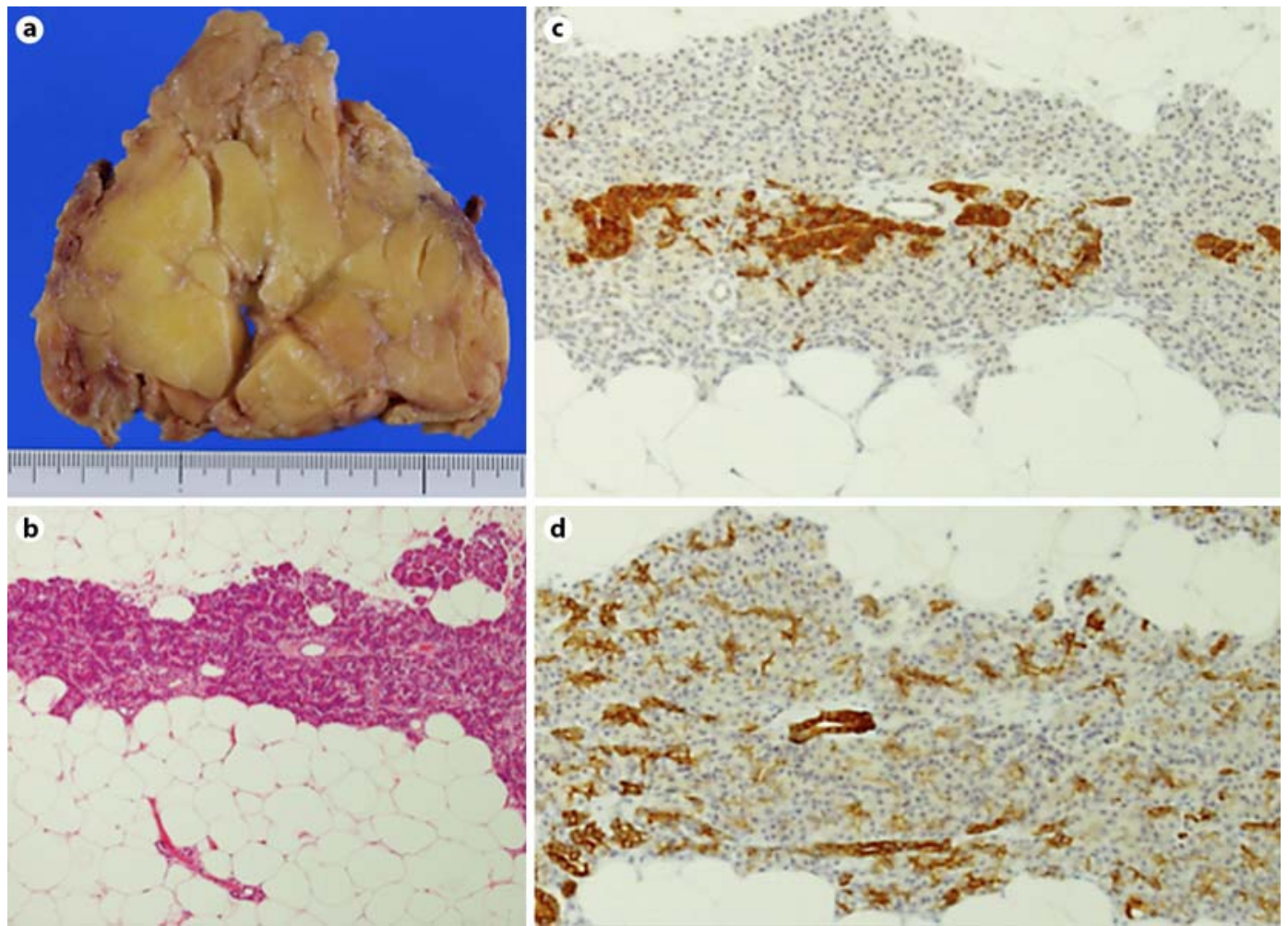

Fig. 4. Histopathological findings. The operative specimen was yellow, soft, elastic, and lobulated, resembling adipose tissue (maximum diameters $18.0 \times 11.0 \times 6.0 \mathrm{~cm}$ ), and weighed about $600 \mathrm{~g}(\mathbf{a})$. Proliferation of mature adipose tissue was seen throughout the mass. Islands of acinar tissue remained at the periphery of the tumor mass, and fine pancreatic ducts were present within the fatty tissue (b). Immunohistochemical staining of the specimen showed expression of chromogranin A in the islets of Langerhans (c), and cytokeratin 19 was detected in the epithelial cells of pancreatic ducts (d).

\section{References}

1 Hantelmann W: Fettsucht und Atrophie der Bauchspeicheldrüse bei Jugendlichen. Virchows Arch 1931;282:630-642.

2 Hoyer A: Lipomatous pseudohypertrophy of the pancreas with complete absence of exocrine tissue. J Pathol Bacteriol 1949;61:93-100.

-3 Beresfold OD, Owen TK: Lipomatous pseudohypertrophy of the pancreas. J Clin Path 1957;10:63-66.

4 Siegler DIM: Lipomatous pseudohypertrophy of the pancreas associated with chronic pulmonary suppuration in an adult. Postgrad Med J 1974;50:53-55.

5 Nakamura M, Katada N, Sakakibara A, et al: Huge lipomatous pseudohypertrophy of the pancreas. Am J Gastroenterol 1979;72:171-174.

6 Yoshimura N, Hayashi S, Fukushima Y: Diffuse Mallory bodies in the liver, diffuse Lewy bodies in the brain and diffuse fat replacement (lipomatous pseudohypertrophy) of the pancreas in a patient with juvenile Parkinson's disease. Acta Pathol Jpn 1992;42:826-831.

7 Bralet MP, Terris B, Bregeaud L, et al: Squamous cell carcinoma and lipomatous pseudohypertrophy of the pancreas. Virchows Arch 1999;434:569-572.

8 Salm R: Scirrhous adenocarcinoma arising in a lipomatous pseudohypertrophic pancreas. J Pathol Bacteriol 1960;79:47-52.

-9 Sasaki M, Nakamura Y, Ando H: Lipomatous pseudohypertrophy of the pancreas in a patient with cirrhosis due to chronic hepatitis B. Pathol Int 1998;48:566-568. 
10 Kuroda N, Okada M, Toi M, Hiroi M, Enzan H: Lipomatous pseudohypertrophy of the pancreas: further evidence of advanced hepatic lesion as the pathogenesis. Pathol Int 2003;53:98-101.

$\checkmark 11$ Robson HN, Scott GBD: Lipomatous pseudohypertrophy of the pancreas. Gastroenterology 1953;23:74-81.

12 Yamamoto A, Fujimura M, Hirano M, et al: Three cases with fatty replacement of the pancreas (in Japanese with English abstract). Suizou (Pancreas) 1992;7:637-644.

13 Tanaka K, Fukata S, Kawabata Y, et al: A case of lipomatous pseudohypertrophy of the pancreas (in Japanese with English abstract). Nihon Rinsyougeka Gakkaizasshi (Jpn Clin Surg) 2005;66:1452-1456.

14 Ueki T, Mizuno M, Nakagawa M, et al: A case of diffuse fatty replacement of the pancreas which guessed lipomatous pseudohypertrophy of the pancreas (in Japanese). Tan to Sui 2006;27:259-262.

15 Tanya F, Hugo B, Nathan S, et al: Liver transplantation in a patient with primary sclerosing cholangitis suffering from lipomatous pseudohypertrophy of the pancreas. Eur Soc Organ Transplant 2008;21:89-91.

16 Altinel D, Basturk O, Sarmiento JM, et al: Lipomatous pseudohypertrophy of the pancreas: a clinicopathologically distinct entity. Pancreas 2010;39:392-397. 